\title{
Morphology and molecular evaluation of Iphinoe spelaeobios gen. nov., sp. nov. and Loriellopsis cavernicola gen. nov., sp. nov., two stigonematalean cyanobacteria from Greek and Spanish caves
}

\author{
V. Lamprinou, ${ }^{1}$ M. Hernández-Mariné, ${ }^{2}$ T. Canals, ${ }^{2}$ K. Kormas, ${ }^{3}$ \\ A. Economou-Amilli ${ }^{1}$ and A. Pantazidou ${ }^{1}$ \\ ${ }^{1}$ University of Athens, Faculty of Biology, Department of Ecology and Systematics, \\ Panepistimiopolis, Athens 15 784, Greece \\ ${ }^{2}$ University of Barcelona, Faculty of Pharmacy, Botany, Av. Joan XXIII s/n, E-08028 Barcelona, \\ Spain \\ ${ }^{3}$ University of Thessaly, Department of Ichthyology and Aquatic Environment, School of Agricultural \\ Sciences, Nea lonia 38 446, Greece
}

\begin{abstract}
Caves have generally been found to host phototrophic micro-organisms from various taxonomic groups, with cyanobacteria comprising an important group that have adapted to these stable and highly specific environments. A polyphasic study based on aspects of classical morphology and molecular data revealed two new monospecific genera from fresh material of Greek and Spanish caves. Both taxa are characterized by obligatory true branching (T-type, V-type and false branching), the presence of heterocysts, and reproduction by hormocysts and akinetes. They shared some similarities in their morphological characteristics as revealed by light, scanning electron and transmission electron microscopy, but phylogenetic analysis based on 16S rRNA gene sequences showed that the two phylotypes were different ( $89.8 \%$ similarity); this represents an example of shared morphology in genetically different strains of cave-adapted species. Phenotypic and genetic traits strongly support classification of the phylotypes as independent taxa in the order Stigonematales (the most differentiated and complicated group of cyanobacteria), family Loriellaceae Geitl 1925. Hence, the names Iphinoe spelaeobios Lamprinou and Pantazidou gen. nov., sp. nov. and Loriellopsis cavernicola Hernández-Mariné and Canals gen. nov., sp. nov. are proposed.
\end{abstract}

Caves represent a stable ecosystem where light controlling the growth of photosynthetic organisms is the limiting factor (Hernández-Mariné \& Canals, 1994; Asencio \& Aboal, 1996). However, a variety of microhabitats for autotrophic growth is created when adequate natural light reaches the inner part of the caves or when artificial lights are installed.

There have been many studies concerning the photosynthetic microflora of these unique environments worldwide (Borzi, 1917; Chu, 1952; Chu et al., 1991; Friedmann, 1955, 1964; Şerbãnescu \& Decu, 1962; Claus, 1962, 1964; Hajdu,

Abbreviations: LM, light microscopy; PAR, photosynthetically active radiation; $\mathrm{RH}$, relative humidity; SEM, scanning electron microscopy; TEM, transmission electron microscopy.

The GenBank/EMBL/DDBJ accession numbers for the 16S rRNA gene sequences of Iphinoe spelaeobios LO2-B1 and Loriellopsis cavernicola LF-B5 are HM748317 and HM748318, respectively.
1966; Golubić, 1967; Skuja, 1970; Bourrelly \& Dupuy, 1973; Dobat, 1977; Leclerc et al., 1983; Abdelahad, 1989; Sant'Anna et al., 1991; Aboal et al., 1994; Asencio \& Aboal, 1996, 2000; Ariño et al., 1997; Vinogradova et al., 1998; Dor \& Dor, 1999; Hernández-Mariné et al., 2001; Roldán et al., 2004; Pantazidou \& Roussomoustakaki, 2005; Lamprinou et al., 2009; Roldán \& Hernández-Mariné, 2009). Despite the fact that Greece has more than 8000 karstic caves, since limestone is the dominant rock over the land area, studies on cave microflora are scarce (Anagnostidis et al., 1982; IliopoulouGeorgoudaki et al., 1993; Pantazidou, 1996, 1997; Pantazidou \& Roussomoustakaki, 2005; Lamprinou et al., 2009). A similar situation is observed in Spain, even though several caves are known, mainly in the Mediterranean area (GraciaAlonso, 1974; Asencio \& Aboal, 1996, 2000; Beltrán \& Asencio, 2009; Hernández-Mariné et al., 2001; Roldán et al., 2004; Roldán \& Hernández-Mariné, 2009). 
New genera of the Stigonematales (Spelaeopogon, Geitleria) and Chroococcales (Asterocapsa), as well as a number of novel species, have been established from cave ecosystems including Spelaeopogon sommierii Borzi 1917, Asterocapsa gloeotheceformis Chu 1952, Asterocapsa hyalina Chu 1952, Asterocapsa trochiscioides (Jao) Chu 1952, Chroococcidiopsis kashaii Friedmann 1961, Geitleria calcarea Friedmann 1955, Geitleria floridana Friedmann 1979, Asterocapsa longipapilla Liu 1985, Gloeothece filiformis Sant'Anna et al. 1991, Herpyzonema pulverulentum HernándezMariné and Canals 1994, and Symphyonema cavernicolum Asencio et al. 1996.

Species identification within the cyanobacteria is based mainly on aspects of morphology, according to classical literature (Geitler, 1932; Desikachary, 1959; Anagnostidis \& Komárek, 1985, 1988, 1990; Komárek \& Anagnostidis, $1986,1989,1998,2005)$. However, the recent application of molecular tools offers the potential to resolve much of the controversy over cyanobacterial taxonomy, evolution and the species concept (Wilmotte, 1994; Hoffmann et al., 2005). As a result, a polyphasic approach to taxonomic identification is currently being adopted.

Using a polyphasic approach, members of two new monospecific genera of Stigonematales, Iphinoe spelaeobios gen. nov., sp. nov. and Loriellopsis cavernicola gen. nov., sp. nov., are proposed based on examination of natural and cultured material from Greek caves ('Koutouki' and 'Kastria') and a Spanish cave ('Papellona') by light (LM) and electron [transmission (TEM) and scanning (SEM)] microscopy, as well as by $16 \mathrm{~S}$ rRNA gene sequencing. Both phenotypic and 16S rRNA gene-based phylogenetic analyses confirm that the two new genera belong to Stigonematales, the most differentiated and complicated order of the cyanobacteria (Anagnostidis \& Komárek, 1990).

Cave 'Koutouki' (37 56' 45.84" N $\left.23^{\circ} 49^{\prime} 43.46^{\prime \prime} \mathrm{E}\right)$, a popular tourist spot near Paeania, is on the eastern side of Mount Hymettus (Attica, Greece). It is a vertical cave with an entry shaft $38.5 \mathrm{~m}$ deep, opening at the bottom into a single huge cavern $(60 \times 60 \mathrm{~m})$. Material was collected from dimly lit sites illuminated with artificial light. Cave 'Kastria' ( $37^{\circ} 57^{\prime} 37.54^{\prime \prime} \mathrm{N} 22^{\circ} 08^{\prime} 26.91^{\prime \prime} \mathrm{E}$ ) is located in Peloponnese, Greece, and is an old subterranean river with an explored length of $1980 \mathrm{~m}$. The part of the cave that is open to tourists is currently $500 \mathrm{~m}$ long with a separate entrance. Material was collected from part of the cave that is not open to tourists near the physical entrance. Cave 'Papellona' $\left(41^{\circ} 17^{\prime} 10^{\prime \prime} \mathrm{N} 1^{\circ} 54^{\prime} 49.5^{\prime \prime} \mathrm{E}\right)$, near Barcelona, Spain, is a sinkhole with a wide and shallow entrance (about $3 \mathrm{~m}$ ) that is bifurcated at its end into two wings (Papellona in Catalan means butterfly); one wing is practically horizontal and the other one is a well of $3 \mathrm{~m}$ depth.

Air temperature $\left({ }^{\circ} \mathrm{C}\right)$, relative humidity $(\mathrm{RH} ; \%)$ and photosynthetically active radiation (PAR; $\mu \mathrm{mol} \mathrm{m} \mathrm{m}^{-2} \mathrm{~s}^{-1}$ ) were measured in Greek caves using a LI-1400 data logger (LI-COR
Biosciences) and these parameters were determined in the Spanish cave using a Squirrel Data Logger (Grant).

In cave 'Koutouki' during a 4 month survey, the mean air temperature was $15.7-16.5^{\circ} \mathrm{C}$, the mean PAR was $0.0203-$ $0.0354 \mu \mathrm{mol} \mathrm{m}^{-2} \mathrm{~s}^{-1}$ and the RH was $92.3-95.1 \%$. In cave 'Kastria' during a 1 year survey, mean air temperature was $6.31-18.50{ }^{\circ} \mathrm{C}$, PAR was $0.0100-0.7750 \mu \mathrm{mol} \mathrm{m}{ }^{-2} \mathrm{~s}^{-1}$ and $\mathrm{RH}$ was $88.06-97.76 \%$.

In cave 'Papellona', air temperature gradually stabilized to around $10{ }^{\circ} \mathrm{C}$ up to the deepest zone of the cavity $(>6 \mathrm{~m})$, $\mathrm{RH}$ increased up to $60 \%$ and PAR decreased to below the threshold of the sensor $\left(<1 \mu \mathrm{mol} \mathrm{m}{ }^{-2} \mathrm{~s}^{-1}\right)$ (Roldán et al., 2004).

Samples from all caves were taken at different distances from the physical cave entrances and from selected sites inside the caves representing distinct environmental conditions and hosting various cyanobacteria. Sampling from the Greek caves was conducted monthly from May to August 2008 ('Koutouki') or seasonally in 2009 ('Kastria'). Samples from cave 'Papellona' have been collected at irregular intervals since 1988 up to the present.

Collected material was partly fixed with formaldehyde solution at a final concentration of $2.5 \%$ and partly kept alive for culturing. Enrichment cultures were obtained in flasks and Petri dishes with BG11 (Stanier et al., 1971) and BBM (Bischoff \& Bold, 1963) liquid media. Cultures were maintained in an incubator (Gallenkamp; Sanyo) under stable conditions and in daylight (north-facing window) at room temperature. Cultures were kept alive for 3 months only; attempts to grow and maintain the species under study in cultures are in progress.

For LM, natural and cultured material was observed on glass slides under a high-resolution light microscope (Photomicroscope III; Zeiss). In order to dissolve sheath encrustation, material was examined after treatment with Pereny's solution $\left(10 \% \mathrm{HNO}_{3}, 0.5 \% \mathrm{Cr}_{2} \mathrm{O}_{3}, 95 \%\right.$ $\mathrm{C}_{2} \mathrm{H}_{5} \mathrm{OH}$ at $4: 3: 3$ ) (Bornet \& Flahault, 1889).

For SEM, specimens from Greece were dehydrated in an alcohol series (30-100\%), critical-point dried and spraycoated in gold/palladium. They were observed under a JEOL JSM 35 scanning microscope. Specimens from Spain were fixed for 2 days with osmium tetroxide vapour (starting from a $1 \%$ solution), freeze-dried in an Edwards ETD4 tissue drier, gold-coated and observed using a Hitachi-2300 microscope.

For TEM, samples were fixed in a mixture of glutaraldehyde $(2.5 \%)$ in $0.1 \mathrm{M}$ cacodylate buffer for $2-4 \mathrm{~h}$, washed three times in this buffer, decalcified by adding Pereny's solution and post-fixed in $1 \% \mathrm{OsO}_{4}$ in the same buffer. The organisms were dehydrated by a graded acetone series and washed twice in propylenoxide. They were then embedded in three mixtures of propylenoxide and resins $(1 / 0.5,1 / 1$ and $0.5 / 1$, and finally in Spurr's resins. Surface sections were stained with $2 \%$ uranyl acetate and lead citrate as described 
by Reynolds (1963). The sections were examined using a JEOL 1010 TEM at $100 \mathrm{kV}$ accelerating voltage.

DNA was extracted from scraped material from two natural samples in Greece and Spain, using the UltraClean Soil DNA kit (MoBio Laboratories) following the manufacturer's protocol with minor modifications: bead beating was reduced from 10 to $5 \mathrm{~min}$, and this step was immediately followed by three freeze-thaw cycles $\left(-80{ }^{\circ} \mathrm{C}\right.$ for $3 \mathrm{~min}$ and then immediately transferred to a $65{ }^{\circ} \mathrm{C}$ water bath for $5 \mathrm{~min}$ ) after addition of the inhibitor removal solution. Bacterial $16 \mathrm{~S}$ rRNA genes were amplified using the bacterial primers GM3 (5'-AGAGTTTGATCMTGGC-3') (Muyzer et al., 1995) and GM4 (5'-TACCTTGTTACGACTT-3') (Kane et al., 1993). The PCR included an initial denaturation step at $94{ }^{\circ} \mathrm{C}$ for $1 \mathrm{~min}$ followed by $n$ cycles (see below) consisting of $94{ }^{\circ} \mathrm{C}$ for $1 \mathrm{~min}, 44{ }^{\circ} \mathrm{C}$ for $1 \mathrm{~min}$ and $72{ }^{\circ} \mathrm{C}$ for $3 \mathrm{~min}$, and a final extension at $72{ }^{\circ} \mathrm{C}$ for $5 \mathrm{~min}$. The number of cycles was determined after cycle optimization. PCRs were repeated with different cycle numbers and the lowest number of cycles that gave a positive signal ( $n=22$ cycles) was then used for cloning and sequencing in order to minimize PCR bias (Spiegelman et al., 2005). Eight tubes of PCR products were pooled for clean-up and cloning to reduce the bias of each individual reaction.

The combined PCR product was purified using the Montage purification kit (Millipore) and then immediately cloned using the TOPO XL PCR cloning kit (Invitrogen) using electrocompetent cells according to the manufacturer's specifications. A maximum of 24 clones was analysed from each library. These clones were grown in liquid LB medium with kanamycin and their plasmids were purified using the Nucleospin Plasmid QuickPure kit (Macherey-Nagel) for DNA sequencing. Sequence data were obtained by capillary electrophoresis (Macrogen) using the BigDye Terminator kit (Applied Biosystems) with primers M13F (5'-GTAAAACGACGGCCAG- $3^{\prime}$ ) and M13R (5'-CAGGAAACAGCTATGAC-3'). Each sequence read was approximately $850 \mathrm{bp}$. For each individual clone, forward and reverse reads were assembled and then the assembled sequences were checked for chimeras using the CHIMERA-CHECK function of the Ribosomal Database Project II (Maidak et al., 2001). After excluding chimeras and non-cyanobacterial sequences, there were a total of 10 and 18 sequences for LO2 (Greece) and LF (Spain) samples, respectively. The dominant phylotypes were $\mathrm{LO} 2-\mathrm{B1}^{\mathrm{T}}{ }^{\mathrm{T}}$ ( $/ 10$ clones) and $\mathrm{LF}-\mathrm{B} 5^{\mathrm{T}}{ }^{\mathrm{T}}(11 / 18$ clones). Due to this high dominance, no further clones were analysed. The two sequences were compared with the BLAST function (http://blast.ncbi.nlm.nih.gov/Blast.cgi) for detection of closest relatives. Sequence data were compiled using the software MEGA4 (Kumar et al., 2008) and aligned with sequences obtained from GenBank (www.ncbi.nlm.nih.gov) using CLUSTAL_X. Phylogenetic analyses were performed using minimum evolution and parsimony methods implemented in MEGA4 (Kumar et al., 2008). Heuristic searches under minimum evolution criteria used 1000 randomaddition replicates per dataset, each followed by tree bisection-reconnection topological rearrangements. Tree topology was based on neighbour-joining according to Jukes-Cantor. Bootstrapping under parsimony criteria was performed with 1000 replicates.

\section{Description of Iphinoe spelaeobios Lamprinou and Pantazidou gen. nov., sp. nov.}

Iphinoe spelaeobios (I.phi.no'e. N.L. fem. n. Iphinoe named after a Greek nymph inhabiting the cave 'Kastria' in Greek mythology; spe.lae.o'bi.os. Gr. n. spelaion cave, cavern, grotto; Gr. n. bios life, dweller; N.L. n. spelaeobios inhabitant in caves).

The thallus creeps on the calcareous substrate as a whitesilver to purple coating. Filaments are 7-10 (15) $\mu \mathrm{m}$ wide, interwoven with the nostocalean cyanobacterium Scytonema julianum (Kütz) Menegh. Colour of cytoplasm is purplebrown; cell content has granulation. Cells are rather cylindrical or doliform, 5-7 $\mu \mathrm{m}$ wide, $6-10 \mu \mathrm{m}$ long. Apical cells are rounded. Branching is mainly of T-type, rarely of $\mathrm{V}$-type. Heterocysts are intercalary and cylindrical. Reproduces by hormocysts and akinetes.

The phylotype strain is LO2-B1, isolated from a Greek cave. Herbarium of Greece: ATHU-CY 3313M.

Herbarium of Philadelphia (PH), Academy of Natural Sciences: 1088600.

\section{Latin diagnosis of Iphinoe spelaeobios Lamprinou and Pantazidou gen. nov., sp. nov.}

Thallus tectis calce incrustata crassis adsuper serpit plerumque fulvus et purpureus. Fila 7-10 (15) $\mu \mathrm{m}$, colour cytoplasmatis purpureus-fuscus, cellula interiore granulosa. Cellulis praecipue cylindricis vel torulosis, 5-7 $\mu \mathrm{m}$ latis, 6-10 $\mu \mathrm{m}$ longis, apice rotundata. Divergentibus suffultis plerumque modi $\mathrm{T}$, rariter modi $\mathrm{V}$. Heterocystis intercalaribus cylindricis. Multiplicatione hormocystis et akinetibus. Fila intertexta nostocaleano cyanobacterio Scytonema julianum (Kütz) Menegh.

Morphology - LM observations (Fig. 1a-g). Thallus creeps on the calcareous substrate as a white-silver to purple coating. Filaments are usually finely calcified (rarely heavily calcified), variously bent and entangled, 7-10 (15) $\mu \mathrm{m}$ wide (mean $\pm \mathrm{SD}$ is $7.77 \pm 0.935 \mu \mathrm{m} ; n=35$ ). Sheath is colourless, gelatinous, firm and not lamellated. Trichome is mainly cylindrical, slightly constricted at the cross-walls, or torulose. The colour of the cytoplasm is purple-brown and the cell content is granulated. Cells are rather cylindrical or doliform, 5-7 $\mu \mathrm{m}(5.87 \pm 0.68 \mu \mathrm{m}$; $n=35)$ wide and $6-10 \mu \mathrm{m}(8.43 \pm 1.194 \mu \mathrm{m} ; n=35)$ long. Heterocysts are mainly intercalary and solitary in the main axis, and rarely terminal at the ends or at the base of branches; they are 5-8 $\mu \mathrm{m}(6.32 \pm 0.97 \mu \mathrm{m} ; n=35)$ wide and $5-10 \mu \mathrm{m}(7.47 \pm 1.38 \mu \mathrm{m} ; n=35)$ long. Branching is mainly of T-type (lateral), rarely of V-type (dichotomous); false branching is rare, Y-type (reverse-V) is absent, and 

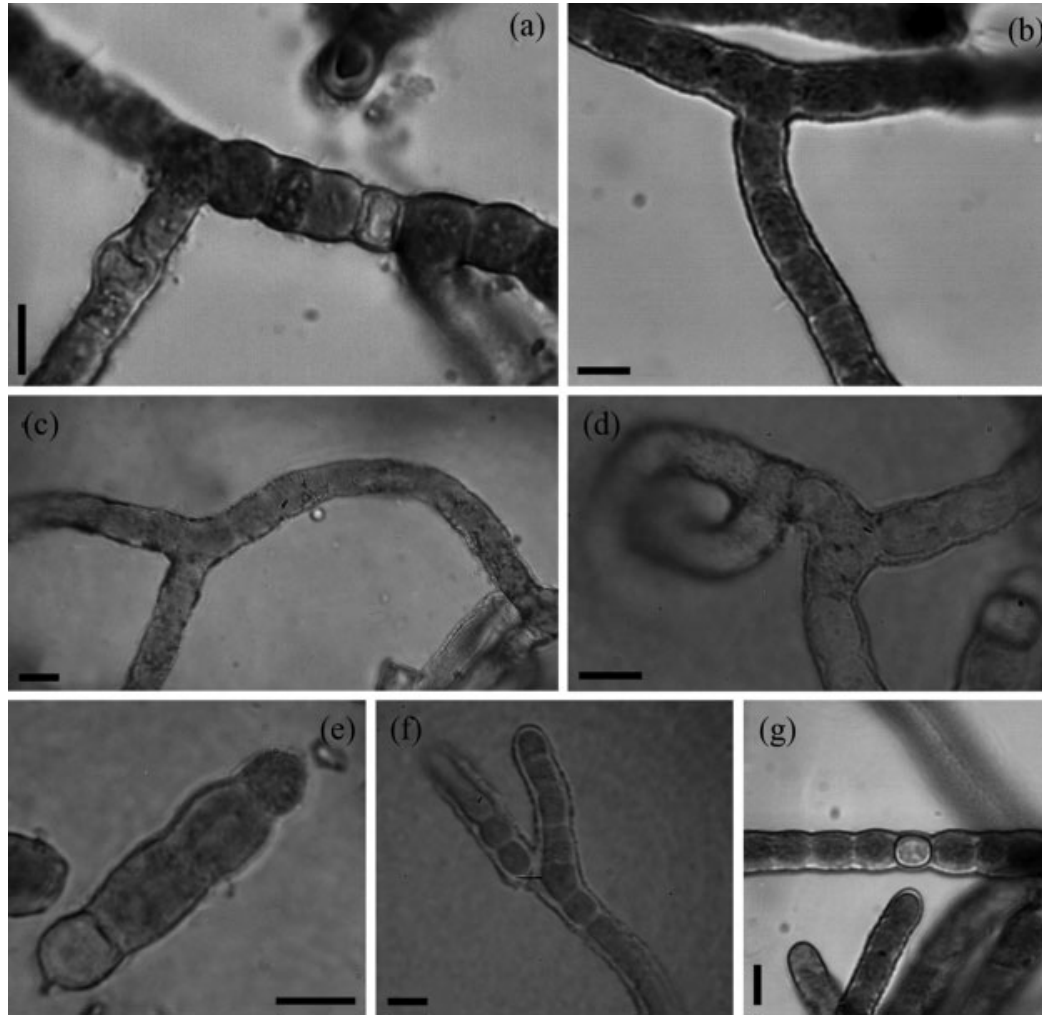

Fig. 1. LM images of Iphinoe spelaeobios gen. nov., sp. nov. showing filaments and type of branching $(a-d)$, hormocyst with terminal heterocyst (e), filament with evidence of the presence of false branching (f) and filament with intercalary heterocyst $(\mathrm{g})$. Bars, $10 \mu \mathrm{m}$. secondary branching is found in both directions with abnormal frequency. Reproduction occurs by uncalcified hormocysts and akinetes. Hormocysts are commonly formed at the end of branches, consisting of 3-8 cells $(20-75 \mu \mathrm{m}$ long) with terminal heterocysts ( $5 \mu \mathrm{m}$ wide and 5-6 $\mu \mathrm{m}$ long); they have the same granulation and colour as the filaments but the sheath is slightly wider. Akinetes are spherical to oblong-spherical, up to $14 \mu \mathrm{m}$ wide, $1-3$ in a row and bigger than ordinary cells. Hormogonia are not observed.

TEM observations (Fig. 2a-g). Thylakoids occupy the whole cell area forming blocks of lamellae, sometimes concentrically arranged. No intercellular connections between vegetative cells are present. Trichome disintegration by necridic cells accompanied by mucilaginous biconcave lamellae formation between cells is observed, leading to trichome breakage and false branching (Fig. 2b).

SEM observations (Fig. $\mathbf{2 h - k}$ ). The sheath is built of small calcite crystals. SEM examination confirms the morphology of the trichomes as being cylindrical or torulose, the dominance of T-type branching (Fig. 2h, i) and the scarce presence of dichotomous V-type branching (Fig. 2k).

\section{Description of Loriellopsis cavernicola Hernández-Mariné and Canals gen. nov., sp. nov.}

Loriellopsis cavernicola [Lo.ri.el.lop'sis. N.L. n. Loriella name of a genus; Gr. fem. n. opsis aspect, appearance; N.L. fem. n. Loriellopsis that which appears similar to
Loriella; ca.ver.ni'co.la. L. n. caverna a hollow, cavity, cave, cavern, grotto; L. suff. -cola (from L. n. incola) inhabitant, dweller; N.L. cavernicola inhabitant in caves].

Thallus is expanded, partially endolithic. Creeps on the substrata, sometimes interwoven with other cyanobacteria. Trichomes are uniseriate, surrounded by a mucilaginous sheath, embedded with calcareous deposits at the base. Trichomes are irregularly branched, at the tips (true Vbranching) and laterally (true T-branching). Cells are cylindrical or torulose, $4.5-6.5 \mu \mathrm{m}$ long and violet. Heterocysts are intercalary. Reproduces by hormocysts. A ring of mucilaginous material helps separation.

The phylotype strain is LF-B5, isolated from a Spanish cave. Herbarium of Spain: BCN-Phyc 6000.

Herbarium of Philadelphia (PH), Academy of Natural Sciences: 1089025.

\section{Latin diagnosis of Loriellopsis cavernicola Hernández-Mariné and Canals gen. nov., sp. nov.}

Thallus indefinitus, partim endolithicus. Stratum saxis calcareis adpressum, vel inter cyanophyceae. Filamenta cum serie singulari cellularum et cum vaginis mucilaginis incoloratis basi calcareo incrustata. Trichomata irregulariter ramose, terminalia dichotoma et lateralia (T). Cellulae cylindricae vel torulosae, 4.5-6.5 $\mu \mathrm{m}$ longae, violaceae. Heterocystae intercalares. Multiplicatio hormocystis inter quas et filamenta corona mucilagina inflate divisionem fovens. 

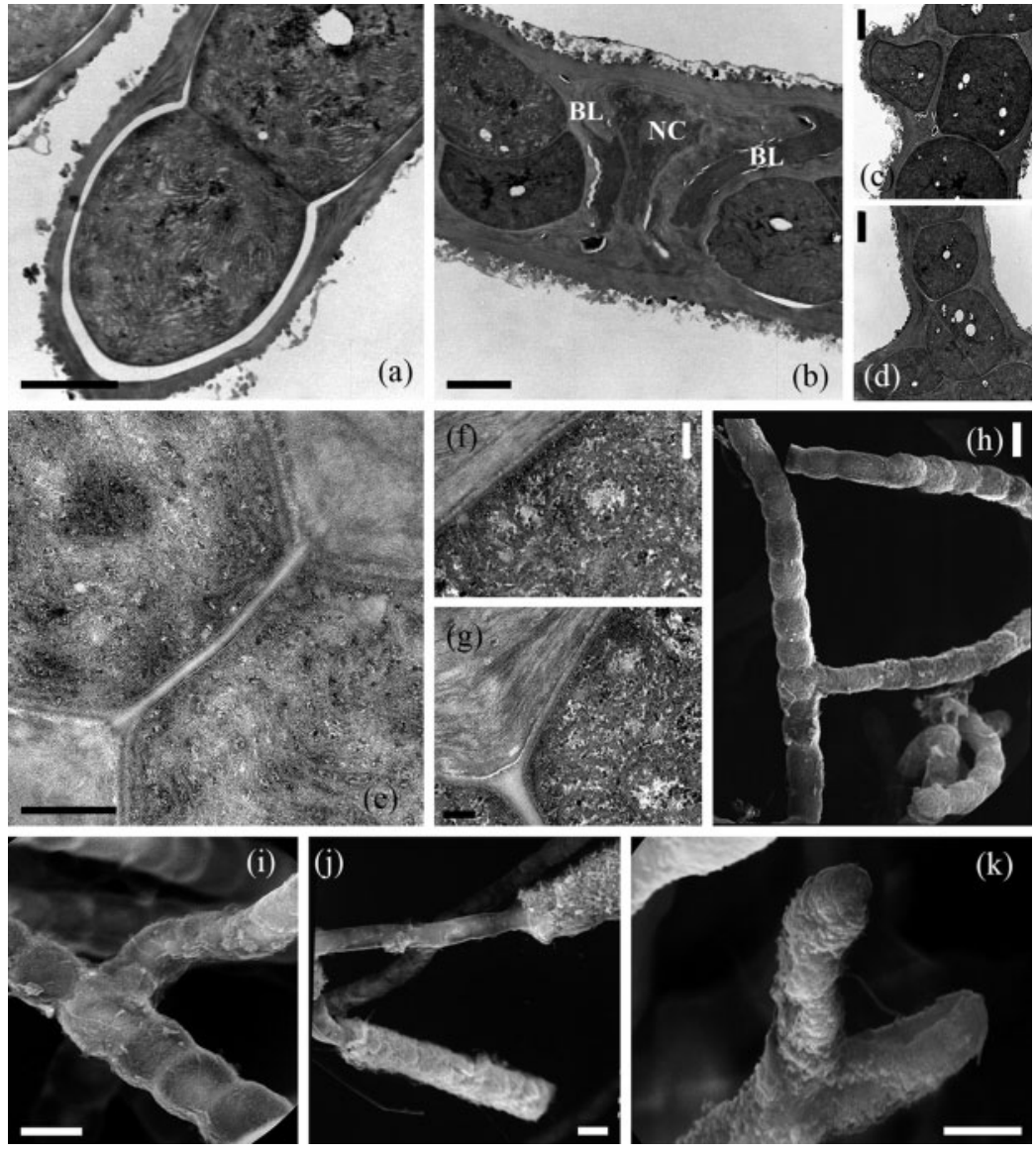

Fig. 2. Micrographs of Iphinoe spelaeobios gen. nov., sp. nov. obtained by TEM $(\mathrm{a}-\mathrm{g})$ and SEM ( $h-k)$ : (a) longitudinal section showing thylakoids occupying the whole cell area; (b) section of a filament showing trichome disintegration with the help of a necridic cell (NC), accompanied by mucilaginous biconcave lamellae formation (BL); (c, d) sections of filaments indicating generation of $\mathrm{T}$ type of branching; (e-g) septum without intercellular connections between vegetative cells; $(h-k)$ calcified sheaths, cylindrical or torulose filaments and type of branching. Bars: $(a-d)$ $2 \mu \mathrm{m}$; (e) $0.5 \mu \mathrm{m}$; (f, g) $0.2 \mu \mathrm{m}$; (h-k) $10 \mu \mathrm{m}$.
Morphology - LM observations (Fig. 3a, b). Thallus is partially endolithic and creeps on the substrata at the cave deep zone, sometimes interwoven with Geitleria calcarea. The colour of the trichome is reddish-purple and the cell content bears yellow-green granulation. Trichomes are uniseriate, laterally true-branched and not differentiated into main and lateral trichomes. Cells are of varying shapes and sizes, short barrel shaped [12.3-6.3 $\mu \mathrm{m}$ (mean \pm SD is $8.29 \pm 1.17 \mu \mathrm{m}$; $n=30)$ wide and $6.7-12.6 \mu \mathrm{m}(9.27 \pm 1.61 \mu \mathrm{m} ; n=30) \mathrm{long}]$ or slightly thinner, doliform to irregular cylindrical cells [3.64-5.9 $\mu \mathrm{m}(4.56 \pm 0.63 \mu \mathrm{m} ; n=30)$ wide and $4.5-8.5 \mu \mathrm{m}$ $[6.55 \pm 2.13 \mu \mathrm{m} ; n=30)$ long]. Terminal cells do not present clear differences in size or shape compared with the rest of the cells. Heterocysts are intercalary and very scarce; they are subspherical or slightly cylindrical, $6 \mu \mathrm{m}$ wide and $6-8 \mu \mathrm{m}$ long. Branching is mainly of T-type (lateral), rarely of V-type (dichotomous); false branching is rare, Y-type (reverse-V) is absent and secondary branching is found in both directions with abnormal frequency. Reproduction occurs by fragmentation of tips or branches, helped by a ring of mucilaginous material, giving rise to hormocysts of 2 to 10 cells, with sheaths slightly or not calcified, and akinetes that are isolated or forming chains.

TEM observations (Fig. 3c, d). Distribution of thylakoids is similar to that observed in I. spelaeobios. Trichome breakage and release of hormocysts occur by enlargement of sheaths in between neighbouring cells. Necridic cells are not observed. Presence of intercellular or pit connections in between some old cells but not at the septum of the thinner terminal ones.

SEM observations (Fig. 3e, f). No calcification is found on the sheath of terminal cells.

\section{Phylogenetic analysis (Fig. 4)}

Phylogenetic analysis showed that the two phylotypes (Iphinoe spelaeobios and Loriellopsis cavernicola) were different (89.8\% similarity). Iphinoe spelaeobios was affiliated within the Stigonematales and was closely related (98.8\% similarity) to an environmental clone (HAVOmat34) from a cyanobacterial mat from a lava cave in Hawaii Volcanoes National Park and also to Symphyonemopsis sp. VAPOR1 (98.9\% similarity), isolated from the El Vapor cave, Spain (Gugger \& Hoffmann, 2004). Loriellopsis cavernicola was not affiliated to any known cyanobacterial taxonomic group and was distantly related (95.4\% similarity) to a different phylotype (HAVOmat106) from the same Hawaii Volcanoes National Park library as above.

\section{Discussion}

The described novel taxa of the new genera Iphinoe and Loriellopsis definitely belong to the order Stigonematales 


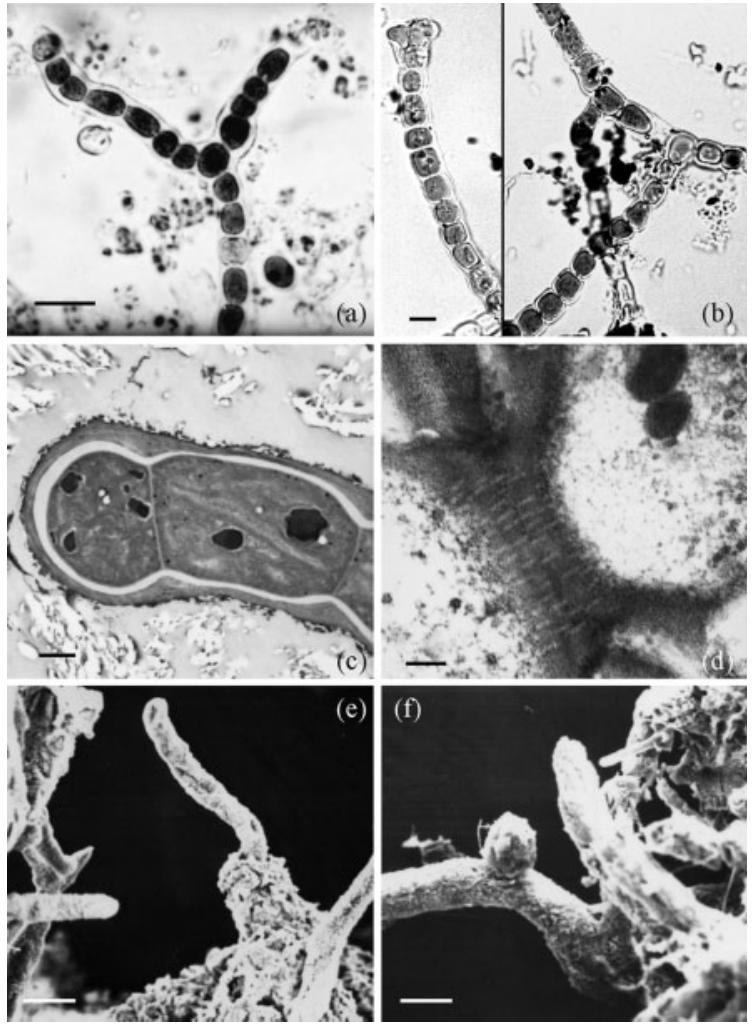

Fig. 3. Micrographs of Loriellopsis cavernicola gen. nov., sp. nov. LM images of decalcified material $(a, b)$ showing filament with intercalary heterocyst and V-branching (a) and filaments with a terminal branch division, generating $V$-branching, and lateral true $T$ and false branching (b). TEM images (c, d) of longitudinal section showing arrays of parallel thylakoids and cyanophycin granules (c) and septum showing intercellular connections (d). SEM images (e, f) showing filaments calcified at the base (e) and a weakly calcified sheath, with development of a lateral branch (f). Bars: (a, b) $10 \mu \mathrm{m}$; (c) $2 \mu \mathrm{m}$; (d) $0.1 \mu \mathrm{m}$; (e, f) $10 \mu \mathrm{m}$.

since they display true branching and heterocysts. It is noted that Stigonematales is the most differentiated and complicated group of cyanobacteria, divided into eight families according to Anagnostidis \& Komárek (1990); apart from the presence of heterocysts, this order is characterized by various types of true branching (X-, T-, V-, Y-type) (Anagnostidis \& Komárek, 1990; Golubić et al., 1996), an obligatory character sometimes combined with false branching.

Specifically, the observed type of branching (mainly T-type, rarely $\mathrm{V}$-type) and the mode of reproduction (hormocysts and akinetes) in Iphinoe spelaeobios and Loriellopsis cavernicola indicate that they are closely related to the families Loriellaceae Geitler 1925 and Mastigocladaceae Geitler 1925 of the order Stigonematales (Anagnostidis \& Komárek, 1990). However, Mastigocladaceae is characterized by Y-type of branching and by differentiation of end trichomes, characters that definitely were not observed in our specimens, indicating that the new taxa should be classified in the family Loriellaceae.

From genera included in the Loriellaceae, the monospecific genus Loriella Borzi 1892 (Loriella osteophila Borzi 1892), which is characterized by the formation of hormogonia and by terminal, regularly dichotomous branching, is the most related genus to Iphinoe spelaeobios and Loriellopsis cavernicola. As well as being isolated from material growing on human skulls in Papua New Guinea (Borzi 1892 in Hoffmann, 1990), Loriella osteophila was rediscovered in a neighbouring location on limestone material, specifically in low light environments either on fossil coral debris or at the entry of a small limestone cave, and was considered to be endemic to Melanesia (Hoffmann, 1990). It is noted that a second species, Loriella racovitzae Şerbãnescu in Serbãnescu \& Decu (1962) described from caves of Oltenia (Romania), is considered to be a synonym of Geitleria calcarea since it lacks heterocysts (Bourrelly \& Dupuy, 1973).

Geitleria is another stigonematalean genus described from limestone caves, colonizing the least illuminated areas of the photic zone (type species Geitleria calcarea Friedmann 1955). Two species are classified under this genus, Geitleria calcarea and Geitleria floridana. Geitleria calcarea shares some common morphological characteristics with our specimen of Iphinoe spelaeobios but the absence of heterocysts is a strong evidence for its classification under a different genus.

It is noted that Loriella populations have also been described by Hernández-Mariné et al. (1999) from Spanish limestone caves. These populations share some common characteristics with the type species Loriella osteophila, i.e. dichotomous terminal branching (V-type of branching) and intercalary heterocysts, but differ in other taxonomic features (presence of T-type branching, reproduction by hormocysts) and habitat. Therefore, these populations were not assigned to Loriella osteophila as further molecular investigation is needed. These differences were also observed in the Greek material in this study. Phylogenetic analysis (Fig. 4) based on 16S rRNA gene sequences showed that the two phylotypes (Greek and Spanish) were different ( $89.8 \%$ similarity).

In conclusion, the type of branching (mostly T-type, rarely V-type and also false branching), the mode of reproduction (hormocysts and akinetes) and the absence of dichotomous terminal branching, as well as the absence of intercellular or pit-connections, clearly differentiate the isolates obtained from the Greek caves from the genus Loriella, thus warranting the establishment of a new genus, Iphinoe gen. nov.

Furthermore, 16S rRNA gene sequencing of Iphinoe spelaeobios revealed high similarity $(98.8 \%)$ to an environmental clone (HAVOmat 34 ) and $98 \%$ similarity with a strain (VAPOR1) of the order Stigonematales (Hoffmann et al., 2003), subsequently named Symphyonemopsis sp. 


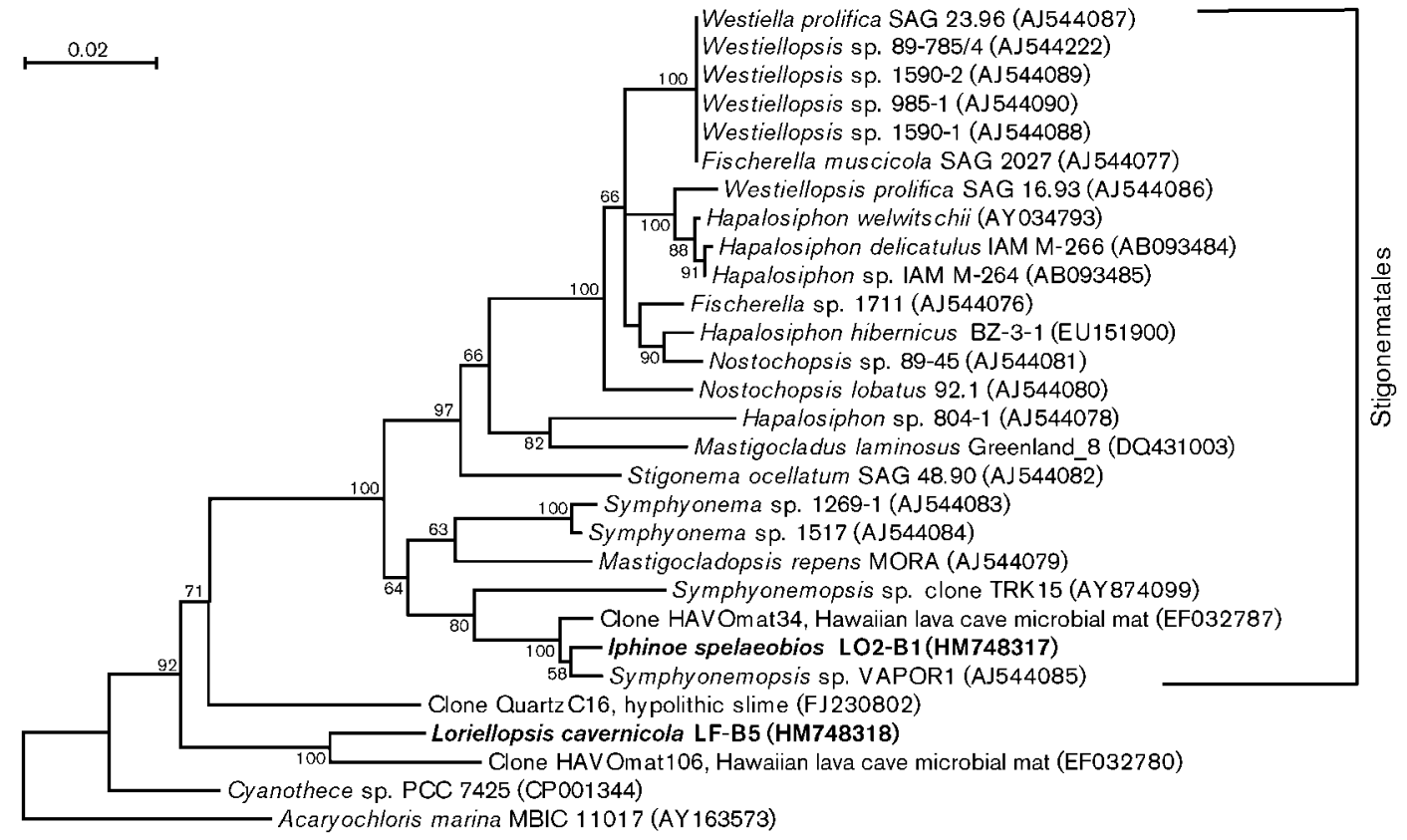

Fig. 4. Phylogenetic tree based on $16 \mathrm{~S}$ rRNA gene sequences showing the distances between the phylotypes Iphinoe spelaeobios LO2-B1 (HM748317) and Loriellopsis cavernicola LF-B5 (HM748318), and related strains. Bar, 0.02 substitutions per site.

(Gugger \& Hoffmann, 2004), that was not similar morphologically to members of any existing genera within the Stigonematales. There are two species within the genus Symphyonemopsis Tiwari and Mitra 1968, Symphyonemopsis katniensis Tiwari and Mitra 1968 and Symphyonemopsis pantii Chadha and Pandey 1978, both established from soil material; this genus is characterized by Y-type branching, multiseriate filaments in all stages, diversification of the main axis from the branches and reproduction by hormocysts and akinetes. Hence, it is a well-defined genus with a morphology that clearly differs from that observed in our material.

Symphyonemopsis sp. VAPOR1 has previously been used in various comparisons (Gugger \& Hoffmann, 2004; Korelusová, 2008), but is not considered to be a typical or reference strain of Symphyonemopsis and, according to Korelusová (2008), is grouped with the false branched Brasilonema, showing possibly the similarities of true and false branching. Due to the absence of fresh and cultured material, it is difficult to adopt a stance on this issue.

The Spanish specimen is established as Loriellopsis cavernicola, a name suggesting the growth environment and also a similarity to Loriella, although in Borzi's description this genus is characterized only by terminal, regularly dichotomous branching ('rami terminales regulariter dichotomi'). Gene sequencing distinguishes this taxon from previously described genera of cyanobacteria. Comparison with database sequences indicated that the 16S rRNA gene of the Spanish material exhibits highest sequence similarity to that of HAVOmat106, the latter described solely on the basis of environmental DNA sequences. The lack of environmental information in the database prevents a further detailed comparison.

The establishment of two new genera in the order Stigonematales, Iphinoe and Loriellopsis, is based on both the molecular evaluation of genotypes and phenotypic characters, as an integral part of generic definition (Komárek, 2010b) which must be continually corrected and updated (Hoffmann et al., 2005). The species Iphinoe spelaeobios and Loriellopsis cavernicola represent an example of shared morphology in genetically different strains. Both are components of natural populations in a highly specialized environment, with a disjointed and worldwide distribution (Hernández-Mariné et al., 1999), where dim light seems to be a major stress factor. The morphological similarity with previously reported morphospecies could be attributed to highly convergent forms that can obscure taxonomic relationships among cave-adapted species (Porter, 2007). Additional molecular characters could help in the identification of those morphologically similar types that are indistinguishable or barely distinguishable, known as cryptic species or pseudocryptic species (Casamatta et al., 2003; Komárek, 2010b). In the case of Loriellopsis cavernicola, one of those markers could be the presence of intercellular pit-connections. Moreover, the new taxa must have different microclimatic requirements as revealed by the measured physical parameters and the accompanied species. Scytonema julianum is an ubiquitous species, able to bear strong fluctuations, whereas Geitleria calcarea colonizes the 
surface of stone only under highly specific conditions, including dim light (Ariño et al., 1997). At this time, it is not possible to deduce whether the two novel species are ecologically restricted geographical genotypes or ubiquitous ones, as is the case for Geitleria calcarea which, in spite of its need for a specialized environment, has been found almost worldwide.

Being aware of the new trends in modern classification of 'Nostocales' and 'Stigonematales', we tried to compare our new taxa with other heterozygous and true branched cyanobacteria. It seems that nowadays, according to the molecular evaluation, heterocystous cyanobacteria represent a monophyletic clade (Gugger \& Hoffmann, 2004; Hoffmann et al., 2005; Korelusová, 2008; Komárek 2010a, b; Zammit et al., 2010). However, morphological characters, especially the type of branching, are very important and, as a result, we accept the term 'Stigonematales' according to the botanical code.

Although molecular data seem to be very important for taxonomy, phylogenetic investigation and separation of cryptogenic genera, the use of the 16S rRNA gene alone particularly in view of the fact that cyanobacteria can contain multiple rrn operons and intra-genomic sequence heterogeneity of the $16 \mathrm{~S}$ rRNA gene - seems to be precarious and, thus, multilocus approaches should be applied.

In conclusion, our knowledge of the taxonomy of cyanobacteria, especially the heterocystous cyanobacteria, is still in its infancy and a polyphasic approach using sequences from many genes combined with cytomorphological, ecophysiological and biochemical markers is necessary for the development of cyanobacterial taxonomy.

\section{Acknowledgements}

This work was partially supported by the Special Account of Research Grants of the National and Kapodistrian University of Athens (NKUA Grant 70/04/5717) and by the Spanish Ministerio de Educación y Ciencia (project CGL06-07242). The authors thank Maria Pachiadaki for technical assistance in the molecular analysis, Sofia Papaioannou (Latin diagnosis of Iphinoe spelaeobios), Mónica Ramirez for helping with the plates, and the Scientific and Technical Services of the University of Barcelona.

\section{References}

Abdelahad, N. (1989). On four Myxosarcina-like species (Cyanophyta) living in the Inferniglio cave (Italy). Algol Stud 54, 3-13.

Aboal, M., Asencio, A. D. \& Prefasi, M. (1994). Studies on cave cyanophytes from southeastern Spain: Scytonema julianum (Meneghini ex Franck) Richter. Algol Stud 75, 31-36.

Anagnostidis, K. \& Komárek, J. (1985). Modern approach to the classification system of cyanophytes. 1 - Introduction. Algol Stud 38/ 39, 291-302.

Anagnostidis, K. \& Komárek, J. (1988). Modern approach to the classification system of cyanophytes. 3 - Oscillatoriales. Algol Stud 50-53, 327-472.
Anagnostidis, K. \& Komárek, J. (1990). Modern approach to the classification system of cyanophytes. 5 - Stigonematales. Algol Stud 59, 1-73.

Anagnostidis, K., Economou-Amili, A. \& Pantazidou, A. (1982). Studies on the microflora of the cave Perama, Ioannina, Greece. Bull Soc Spéléol Grèce 18, 458-530.

Ariño, X., Hernández-Mariné, M. \& Saiz-Jiménez, C. (1997). Colonization of Roman tombs by calcifying cyanobacteria. Phycologia 36, 366-373.

Asencio, A. \& Aboal, M. (1996). Cyanophytes from Andragulla abrigo (Murcia, SE Spain) and their environmental conditions. Algol Stud 83, 55-72.

Asencio, A. \& Aboal, M. (2000). Algae from La Serreta cave (Murcia, SE Spain) and their environmental conditions. Algol Stud 96, 59-78.

Beltrán, J. A. \& Asencio, A. (2009). Cyanophytes from the L'Aigua cave (Alicante, SE Spain) and their environmental conditions. Algol Stud 132, 21-34.

Bischoff, H. W. \& Bold, H. C. (1963). Phycological studies IV. Some soil algae from Enchanted Rock and related algal species. Texas: University of Texas.

Bornet, E. \& Flahault, C. (1889). Sur quelques plantes vivant dans le test calcaire des Mollusques. Bull Soc Bot France 36, 147-176.

Borzi, A. (1917). Studi sulle Mixoficee. Nuov Giorn Bot Ital 24, 100112.

Bourrelly, P. \& Dupuy, P. (1973). Quelques stations françaises de Geitleria calcarea, Cyanophycée cavernicole. Schweiz Z Hydrol 35, $136-140$

Casamatta, D. A., Vis, M. L. \& Sheath, R. G. (2003). Cryptic species in cyanobacterial systematics: a case study of Phormidium retzii (Oscillatoriales) using RAPD molecular markers and 16S rDNA sequence data. Aquat Bot 77, 295-309.

Chu, H. (1952). Some new Myxophyceae from Szechwan province China. Ohio J Sci 21, 96-101.

Chu, H., Zhu, W. \& Li, Y. (1991). Chroococcophyceae. In Flora Algarum Sinicarum Aquae Dulcis II, p. 161. Edited by H. Chu. Beijing: Science Press.

Claus, G. (1962). Beiträge zur kenntnis der algenflora der abaligeter höhle. Hydrobiologia 19, 192-222.

Claus, G. (1964). Algae and their mode of life in the Baradla Cave at Aggtelek. Int J Speleol 1, 13-17.

Desikachary, T. V. (1959). Cyanophyta. ICAR Monographs on Algae. New Delhi: Indian Council of Agricultural Research.

Dobat, K. (1977). Zur Ökogenese und Ökologie der Lampenflora deutscher Schauhohlen. In Beitrage zur Biologie der niederen Pflanzen, pp. 177-215. Edited by W. Frey. Stuttgart: Gustav Fischer Verlag.

Dor, I. \& Dor, Y. (1999). Cyanobacterial flora of the Soreq stalactite Cave (Israel) and way of its control. Algol Stud 94, 115-120.

Friedmann, I. (1955). Geitleria calcarea n. gen. et n. sp. - a new atmophytic lime-incrusting blue-green alga. Bot Not 108, 439-445.

Friedmann, I. (1964). Progress in the biological exploration of caves and subterranean waters in Israel. Int J Speleol 1, 29-33.

Geitler, L. (1932). Cyanophyceae. Leipzig: Akademische Verlagsgesellschaft.

Golubić, S. (1967). Algenvegetation der Felsen, eine ökologische Algenstudie im dinarischen Karstgebeit. Stuttgart: Schweizerbart.

Golubić, S., Hernández-Mariné, M. \& Hoffmann, L. (1996). Developmental aspects of branching in filamentous Cyanophyta/ Cyanobacteria. Algol Stud 83, 303-329.

Gracia-Alonso, C. A. (1974). Geitleria calcarea Friedmann nueva alga cavernicola para España. Speleon 21, 133-136. 
Gugger, M. F. \& Hoffmann, L. (2004). Polyphyly of true branching cyanobacteria (Stigonematales). Int J Syst Evol Microbiol 54, 349-357.

Hajdu, I. (1966). Algological studies in the cave of Matyas Mount, Budapest, Hungary. Int J Speleol 2, 137-149.

Hernández-Mariné, M. \& Canals, T. (1994). Herpyzonema pulverulentum (Mastigocladaceae), a new cavernicolous atmophytic and lime-incrusted cyanophyte. Algol Stud 75, 123-136.

Hernández-Mariné, M., Asencio, A., Canals, A., Ariño, X., Aboal, M. \& Hoffmann, L. (1999). Discovery of populations of the lime-incrusting genus Loriella (Stigonematales) in Spanish caves. Algol Stud 94, 121-138.

Hernández-Mariné, M., Roldán, M., Clavero, E., Canals, A. \& Ariño, X. (2001). Phototrophic biofilm morphology in dim light. The case of the Puigmoltó sinkhole. Nova Hedwigia 123, 237-253.

Hoffmann, L. (1990). Rediscovery of Loriella osteophila (Cyanophyceae). Br Phycol J 25, 391-395.

Hoffmann, L., Gugger, M. \& Asencio, A. (2003). Morphological and molecular characterisation of a stigonematalean cyanobacterium isolated from Spanish cave. Algol Stud 109, 259-265.

Hoffmann, L., Komárek, J. \& Kaštovský, J. (2005). System of cyanoprokaryotes (cyanobacteria)-state in 2004. Algol Stud 117, 95-115.

Iliopoulou-Georgoudaki, J., Pantazidou, A. \& Theoulakis, P. (1993). An assessment of cleaning photoautotrophic microflora: the case of Perama cave, Ioannina Greece. Mem Biospeol 20, 117-120.

Kane, M. D., Poulsen, L. K. \& Stahl, D. A. (1993). Monitoring the enrichment and isolation of sulfate-reducing bacteria by using oligonucleotide hybridization probes designed from environmentally derived 16S rRNA sequences. Appl Environ Microbiol 59, 682-686.

Komárek, J. (2010a). Modern taxonomic revision of planktic nostocalean cyanobacteria: a short review of genera. Hydrobiologia 639, 231-243.

Komárek, J. (2010b). Recent changes (2008) in cyanobacteria taxonomy based on a combination of molecular background with phenotype and ecological consequences (genus and species concept). Hydrobiologia 639, 245-259.

Komárek, J. \& Anagnostidis, K. (1986). Modern approach to the classification system of cyanophytes. 2 - Chroococcales. Algol Stud 74, 157-226.

Komárek, J. \& Anagnostidis, K. (1989). Modern approach to the classification system of cyanophytes. 4 - Nostocales. Algol Stud 74, 247-345.

Komárek, J. \& Anagnostidis, K. (1998). Cyanoprocaryota, 1. Teil: Chroococcales Süsswasserflora von Mitteleuropa 19/1. Stuttgart: G. Fischer Verlag.

Komárek, J. \& Anagnostidis, K. (2005). Cyanoprocaryota, 2. Teil: Oscillatoriales. Süsswasserflora von Mitteleuropa 19/2. Heidelberg: Elsevier/Spectrum.

Korelusová, J. (2008). Phylogeny of heterocystous cyanobacteria (Nostocales and. Stigonematales). MSc thesis, Faculty of Science, University of South Bohemia, České Budějovice.

Kumar, S., Nei, M., Dudley, J. \& Tamura, K. (2008). MEGA: a biologistcentric software for evolutionary analysis of DNA and protein sequences. Brief Bioinform 9, 299-306.

Lamprinou, V., Pantazidou, A., Papadogiannaki, G., Radea, C. \& Economou-Amili, A. (2009). Cyanobacteria and associated invertebrates in Leontari cave. Fottea 9, 155-164.

Leclerc, J. C., Couté, A. \& Dupuy, P. (1983). Le climat annuel de deux grottes et d'une église du Poitou, où vivant des colonies pures d'algues sciaphiles. Cryptogam Algol 4, 1-19.
Maidak, B. L., Cole, J. R., Lilburn, T. G., Parker, C. T., Jr, Saxman, P. R., Farris, R. J., Garrity, G. M., Olsen, G. J., Schmidt, T. M. \& Tiedje, J. M. (2001). The RDP-II (Ribosomal Database Project). Nucleic Acids Res 29, 173-174.

Muyzer, G., Teske, A., Wirsen, C. O. \& Jannasch, H. W. (1995). Phylogenetic relationships of Thiomicrospira species and their identification in deep-sea hydrothermal vent samples by denaturing gradient gel electrophoresis of $16 \mathrm{~S}$ rDNA fragments. Arch Microbiol 164, 165-172.

Pantazidou, A. (1996). Cyanophytes (cyanobacteria) in lighted parts of various Greek caves - problems associated with their growth. Algol Stud 83, 455-456.

Pantazidou, A. (1997). Cyanobacteria growths on the 5th century BC sculptures and inscription on the limestone walls of cave Nympholypton Greece. In 7th Eurocare-Euromable Workshop ICE/ HT-FORTH, pp. 153-157. Edited by P. G. Koutsoukos and C. G. Kontoyiannis. Patras, Greece: Institute of Chemical Engineering and High Temperature Chemical Processing.

Pantazidou, A. \& Roussomoustakaki, M. (2005). Biodiversity and ecology of cyanobacteria in a variety of hypogean ecosystems (Greece). In 14th International Congress of Speleology, pp. 624-638. Athens, Kalamos, Hellas: Hellenic Speleological Society.

Porter, M. L. (2007). Subterranean biogeography: what have we learned from molecular techniques? J Cave Karst Stud 69, 179-186.

Reynolds, E. S. (1963). The use of lead citrate at high $\mathrm{pH}$ as an electron-opaque stain in electron microscopy. J Cell Biol 17, 208212.

Roldán, M. \& Hernández-Mariné, M. (2009). Exploring the secrets of the three-dimensional architecture of phototrophic biofilms in caves. Int J Speleol 38, 41-53.

Roldán, M., Clavero, E., Canals, A., Gomez-Bolea, A., Ariño, X. \& Hernández-Mariné, M. (2004). Distribution of phototrophic biofilms in cavities (Garraf, Spain). Nova Hedwigia 78, 329-351.

Sant'Anna, C., Branco, L. \& Silva, S. (1991). A new species of Gloeothece (Cyanophyceae, Microcystaceae) from São Paulo State, Brazil. Algol Stud 92, 1-5.

Şerbãnescu, V. \& Decu, M. (1962). To the knowledge of cavernicolous algae of Oltenia. Rev Biol 7, 201-214.

Skuja, H. (1970). Alghe cavernicole nelle zone illuminate delle grotte di Castellana (Murge di Bari). Le Grotte d'Italia 4, 193-202.

Spiegelman, D., Whissell, G. \& Greer, C. W. (2005). A survey of the methods for the characterization of microbial consortia and communities. Can J Microbiol 51, 355-386.

Stanier, R. Y., Kunisawa, R., Mandel, M. \& Cohen-Bazire, G. (1971). Purification and properties of unicellular blue-green algae (order Chroococcales). Bacteriol Rev 35, 171-205.

Vinogradova, O. N., Kovalenko, O. V., Wasser, S. P., Nevo, E. \& Weinstein-Evron, M. (1998). Species diversity gradient to darkness stress in blue-green algae/cyanobacteria: microscale test in a prehistoric cave, Mount Carmel, Israel. Isr J Plant Sci 46, 229-238.

Wilmotte, A. (1994). Molecular evolution and taxonomy of the cyanobacteria. In The Molecular Biology of Cyanobacteria, pp. 1-25. Edited by D. A. Bryant. Dordrecht: Kluwer Academic.

Zammit, G., Kaštovský, J. \& Albertano, P. (2010). A first cytomorphological and molecular characterisation of a new Stigonematalean cyanobacterial morphotype isolated from Maltese catacombs. Algol Stud 135, 1-14. 